\title{
Rapid recycling of coral mass-spawning products in permeable reef sediments
}

\author{
Christian Wild $^{1, *}$, Ralph Tollrian ${ }^{2}$, Markus Huettel $^{3}$ \\ ${ }^{1}$ Max Planck Institute for Marine Microbiology, Celsiusstrasse 1, 28359 Bremen, Germany \\ ${ }^{2}$ Department Biology II and GeoBioCenter, Ludwig-Maximilians University, Karlstraße 23-25, 80333 Munich, Germany \\ ${ }^{3}$ Department of Oceanography, Florida State University, Tallahassee, Florida 32306-4320, USA
}

\begin{abstract}
During the annual synchronous release of gametes by corals, a large amount of energyrich organic material is released to the reef environment. In November 2001, we studied a minor spawning event at Heron Island in the Great Barrier Reef (GBR), Australia. Laboratory experiments showed that egg release by the staghorn coral Acropora millepora amounted to $19 \pm 15 \mathrm{~g}$ dry mass (mean $\pm \mathrm{SE}, \mathrm{n}=8$ ) per $\mathrm{m}^{2}$ coral surface. Carbon content reached $60.1 \pm 4.0 \%$ and nitrogen content $3.6 \pm 0.4 \%$ of the egg dry mass. During this minor spawning period, Acropora corals from the reef crest released $7 \mathrm{~g} \mathrm{C}$ and $0.4 \mathrm{~g} \mathrm{~N}$ as eggs $\mathrm{m}^{-2}$ reef. In situ experiments $(\mathrm{n}=11)$ using stirred benthic chamber measurements revealed that the sedimentary $\mathrm{O}_{2}$ consumption (SOC) of the lagoon sediments increased sharply immediately after the coral spawning. Extreme SOC rates of $230 \mathrm{mmol} \mathrm{O}_{2}$ $\mathrm{m}^{-2} \mathrm{~d}^{-1}$ were reached $2 \mathrm{~d}$ after the event, exceeding the pre-spawning rate by a factor of 2.5 . This maximum was followed by a steep decrease in SOC rates that gradually levelled off and reached prespawning values $11 \mathrm{~d}$ after the event. The immediate and strong response of SOC shows that the coral spawning event provides a strong food impulse to the benthic food chain. Our results demonstrate high decomposition efficiency of permeable carbonate reef sands and underline the role of these sediments as a biocatalytical recycling system in the oligotrophic reef environment.
\end{abstract}

KEY WORDS: Corals · Mass spawning $\cdot$ Permeable sediments $\cdot$ Sedimentary oxygen consumption · SOC $\cdot$ Coral reefs $\cdot$ Recycling

\section{INTRODUCTION}

In 1981, a spectacular phenomenon was discovered by scientists in the Central Great Barrier Reef (GBR), Australia: the synchronous mass release of gametes by many species of coral (Harrison et al. 1984). This event was termed coral spawning, and occurs only on a few predictable nights each year, in the GBR typically during the week following each full moon from October to December (Harrison 1993). Besides the lunar phase, other factors such as temperature change, salinity, current velocity, tidal amplitudes (Oliver et al. 1989, Hayashibara et al. 1993) and even chemical messengers (Atkinson \& Atkinson 1992) are suggested as possible triggers for the coral spawning event. Corals can possibly benefit from the mass release of gametes, because of an enhanced fertilisation success and fast predator satiation (Hughes et al. 2000).

Simultaneous multi-species coral spawning has also been observed in other regions, including Singapore (Guest et al. 2002), Japan (Van Woesik 1995) and the Gulf of Mexico (Gittings et al. 1992, Hagman et al. 1998), but not in the Red Sea (Shlesinger \& Loya 1985) nor the Caribbean (Szmant 1986). Synchronous release of sexual products is also known for a variety of planktonic and other benthic marine invertebrates including polychaetes (Itano \& Buckley 1988), hydrozoan fire corals (Soong \& Cho 1998) and gorgonians (Lasker et al. 1996). It was also observed that green algae on coral reefs show a mass spawning behaviour (Clifton 1997). 
Research in the GBR revealed that at least 140 coral species participate in the mass-spawning event (Babcock et al. 1986, Oliver et al. 1989) that occurs throughout the whole GBR region (Oliver et al. 1989). A broadcast spawning (buoyant gamete release) with external fertilisation is typical for the GBR corals (Harriott 1992). During the very brief spawning period, a large amount of organic matter is released into the reef ecosystem as so-called egg-sperm bundles. The bundles float to the sea surface, because their high lipid content makes them positively buoyant (Arai et al. 1993). Subsequently, the buoyant egg-sperm bundles break apart, releasing eggs and sperm into the surrounding water (Coll et al. 1994). Visible surface aggregations (coral spawn slicks) can form from the coral eggs and embryos as a consequence of local hydrodynamic features such as fronts between water parcels, and wakes and eddies behind a reef (Oliver \& Willis 1987, Willis \& Oliver 1990). Coral eggs and slicks are transported to other reefs by wind and currents (Wolanski et al. 1989, Sammarco et al. 1991) or stay within the same reef due to self-seeding patterns (Andrews et al. 1989, Wolanski et al. 1989).

It is very likely that parts of the released gametic material reach the reef sediments after a short pelagic period, since there is an intense coupling between water column and sediments in these shallow-water environments. Wolanski et al. (1989) found that coral eggs were partly trapped in the lagoon of the studied reef. At Ningaloo Reef, Western Australia, Simpson et al. (1993) observed that large amounts of coral spawn were trapped in a bay and formed extensive slicks on the sediment surface.

In this study we investigated the response of the lagoon sediments to a coral spawning event in order to assess the contribution of the coral sands to the decomposition of the organic material released by the corals. For these investigations, benthic chambers were deployed in the lagoon of the Heron Island Reef, Australia, and the sedimentary $\mathrm{O}_{2}$ consumption (SOC) was measured before, during and after the coral spawning event in November 2001.

\section{MATERIALS AND METHODS}

Study site. All sample collections and experiments were done in November 2001 at Heron Island, a platform-reef system with a total area of $26.4 \mathrm{~km}^{2}$, located in the Southern GBR $\left(23^{\circ} 27^{\prime} \mathrm{S}\right.$, $151^{\circ} 55^{\prime}$ E), Australia (Fig. 1). Egg release was quantified in the laboratory facilities of the Heron Island Research Station (HIRS). The benthic chamber experi- ments took place in Shark Bay, a shallow-water environment (max. water depth $2.5 \mathrm{~m}$ ) situated on the southeastern edge of the island.

Sediment characteristics. We took sediment cores $(\mathrm{n}=7)$ in Shark Bay and measured a permeability of $1.2 \pm 0.34 \times 10^{-10} \mathrm{~m}^{2}$ (mean $\pm \mathrm{SD}$ ) using a constant-head permeameter as described by Klute \& Dirksen (1986). Sediment porosity was $44.3 \pm 1.9 \% \mathrm{wt} / \mathrm{wt}(\mathrm{n}=9) \mathrm{calcu}-$ lated from weight loss of wet sediment after drying at $60^{\circ} \mathrm{C}$ for $24 \mathrm{~h}$. Particulate organic carbon (POC) and nitrogen (PON) contents were measured using a CHNO-rapid elemental analyser (Heraeus) with sulphanilamide as a calibration standard. The samples were pre-treated with $6 \mathrm{~N} \mathrm{HCl}$ until gas development ceased, and then washed twice with distilled water and dried at $60^{\circ} \mathrm{C}$. Measurements showed values of $0.24 \%$ for POC and $0.042 \%$ for PON. The median grain size of Shark Bay sands was $838 \mu \mathrm{m}$, characterising the sediment as dominated by coarse sands.

Egg-release quantification. On 4 November 2001, dominant Acropora species of the Heron Island reef flat were examined for signs of spawning readiness by inspecting the cross-sections of coral branches. Only a few species, A. millepora, A. digitata and A. pulchra, showed pinkish-reddish septal contents, indicating the production of gametes. The other tested species $A$. aspera, A. nobilis and A. formosa did not show any recognisable maturation of eggs. Between 2 and 3 colonies (size approx. $40 \times 40 \times 30 \mathrm{~cm}$ ) from each of the 3 species with visible gametes were collected and

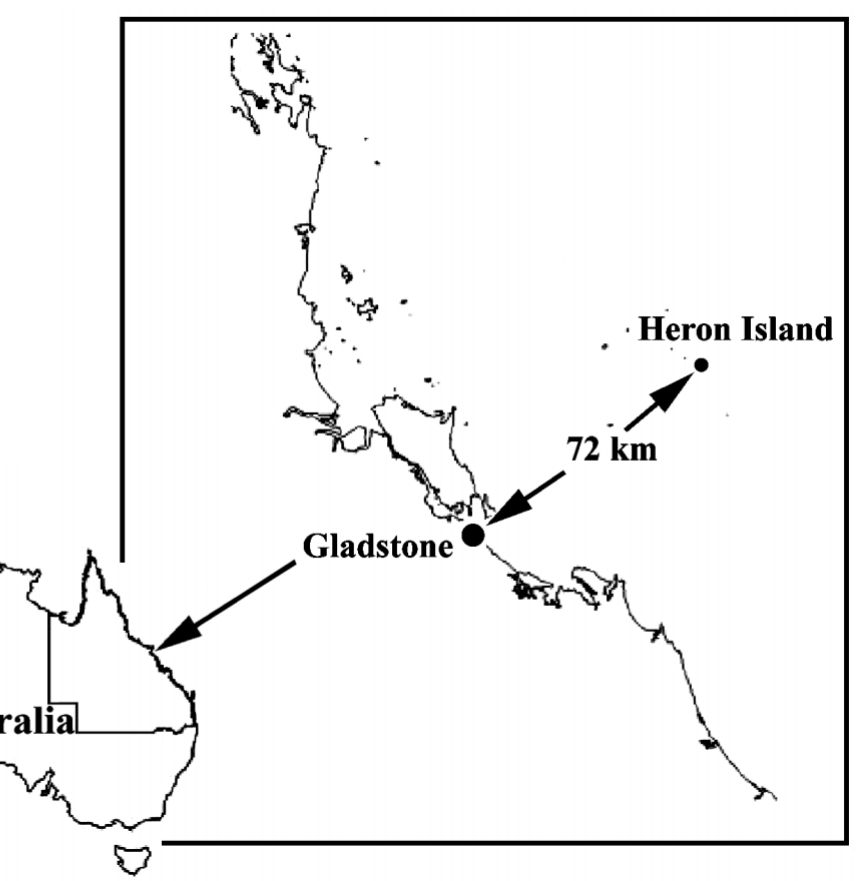

Fig. 1. Location of Heron Island on Australian Great Barrier Reef 
transferred to aerated flow-through tanks at HIRS without exposure to air. One of the A. millepora colonies was split into 8 similar-sized fragments, which were left in a separate aquarium for $3 \mathrm{~d}$ to recover.

Every day at sunset, starting on 7 November 2001, these fragments were transferred to $500 \mathrm{ml}$ glass beakers filled with unfiltered fresh seawater and kept in complete darkness. These beakers were examined for gamete release every 30 min until 22:00 h using a torch covered with a red transparent film. Spawning of all 8 Acropora millepora fragments occurred on 9 November at $21.00 \mathrm{~h}$, lasting for about $45 \mathrm{~min}$ (Fig. 2a). Egg-sperm bundles (Fig. 2d) floating to the water surface of each beaker were filtered through gauze $(50 \mu \mathrm{m})$ to separate eggs and sperm. The eggs then were filtered on pre-weighed Whatman \#1 filters and dried for $48 \mathrm{~h}$ at $40^{\circ} \mathrm{C}$. Egg dry weights were related to the surface area of the parental $A$. millepora fragments. These surface areas were assessed by the wax method described by Stimson \& Kinzie (1991).

Carbon and nitrogen measurements in coral eggs. Freshly released and filtered eggs (sperms were removed) from Acropora millepora, A. digitata and A. pulchra were also dried for $48 \mathrm{~h}$ at $40^{\circ} \mathrm{C}$. Dried eggs were subsequently frozen at $-20^{\circ} \mathrm{C}$ until further analysis. Total organic carbon (TOC) and nitrogen (TON) were measured using an element analyser (Fisons NA1500) with sulphanilamide as the calibration standard.

Determination of sedimentary $\mathrm{O}_{2}$ consumption (SOC). In total, 11 in situ chamber experiments were carried out before, during and after the November coral spawning event. All experiments were done in Shark Bay, always starting $2 \mathrm{~h}$ after low tide (water height approximately $0.5 \mathrm{~m}$ ) and ending between 2 and $7 \mathrm{~h}$ later. Cylindrical stirred benthic chambers, as described in Huettel \& Gust (1992), were used. Plastic lids covered the chambers and were fixed by 4 stainless steel clips. Each lid contained a sampling port with syringe holder for water samples and another port to replace the sampled water. A horizontally rotating disk (20 rpm) agitated the water in the chamber and generated a pressure gradient at the sediment surface of 1.1 Pa between the centre and the chamber wall. Pressure gradients in this order of magnitude develop when sediment topography and boundary flows found at the study site interact (Huettel \& Gust 1992, Glud et al. 1995), and can induce advective transport of water and solutes into permeable sediments. With the chambers used, we were therefore able to generate hydrodynamic conditions very similar to field conditions.

For each experiment, 3 of the benthic chambers were used, with the exception of the first 2 experiments, which used only 1 chamber each because of technical problems. The chambers were inserted gently into the sediment to a depth of about $10 \mathrm{~cm}$, and thus contained a water column of approximately $22 \mathrm{~cm}$ height. The lids then were fitted to the chambers and fixed by clips.

All chambers were protected from light by wrapping them with black PVC foil and secured with weight belts to prevent movement by wind and waves. Recording of light intensity and temperature under the PVC foil and in the surrounding seawater at least every 2 min, using Onset ${ }^{\mathrm{TM}} \mathrm{HOBO}$ and Tidbit dataloggers, showed that no light intrusion and heating took place in the chambers during the in situ incubations. In-situ water temperature was between 22 and $29^{\circ} \mathrm{C}$ in all chamber experiments.

The oxygen concentration in the chamber water was measured at regular intervals using the Winkler titration method (Winkler 1888). SOC was calculated from linear regression of the $\mathrm{O}_{2}$ concentration decrease in the chambers.

Respiration measurements in the water column. In order to quantify the $\mathrm{O}_{2}$ consumption of the water column and to relate it to the results of the chamber experiments, surface water from Shark Bay was collected on 17 November, filled in nine $30 \mathrm{ml}$ Winkler bottles and incubated under dark conditions and at in situ temperature $\left(26-29^{\circ} \mathrm{C}\right)$. The $\mathrm{O}_{2}$ concentrations were measured in a time series using the Winkler titration method, and $\mathrm{O}_{2}$ consumption rates were derived from linear regression of $\mathrm{O}_{2}$ concentrations over time.

\section{RESULTS}

\section{In situ and laboratory observations during the spawning period}

The coral spawning event in November 2001 at Heron Island was not very pronounced. Only a few coral species collected from the Heron Island Reef showed morphological signs of spawning preparation. The release of egg-sperm bundles (Fig. 2c) by corals was directly observed in the laboratory aquarium, but not in the field, although the water temperature on the reef flat (range $22-29^{\circ} \mathrm{C}$ ) was identical with the aquarium temperature (range $22-25^{\circ} \mathrm{C}$ ). Spawning of the corals in the laboratory occurred between 20:30 and 22:00 h on 3 consecutive nights (9-11 November). This was later than the predicted week after full moon (1 November). The spawning event was obviously small, since the typical odour or beach slicks of coral spawning products were not detectable on the mornings during the spawning period. Nevertheless, divers observed slicks of spawning material at the water surface in the lagoon near Shark Bay during high tide on 10 November. 


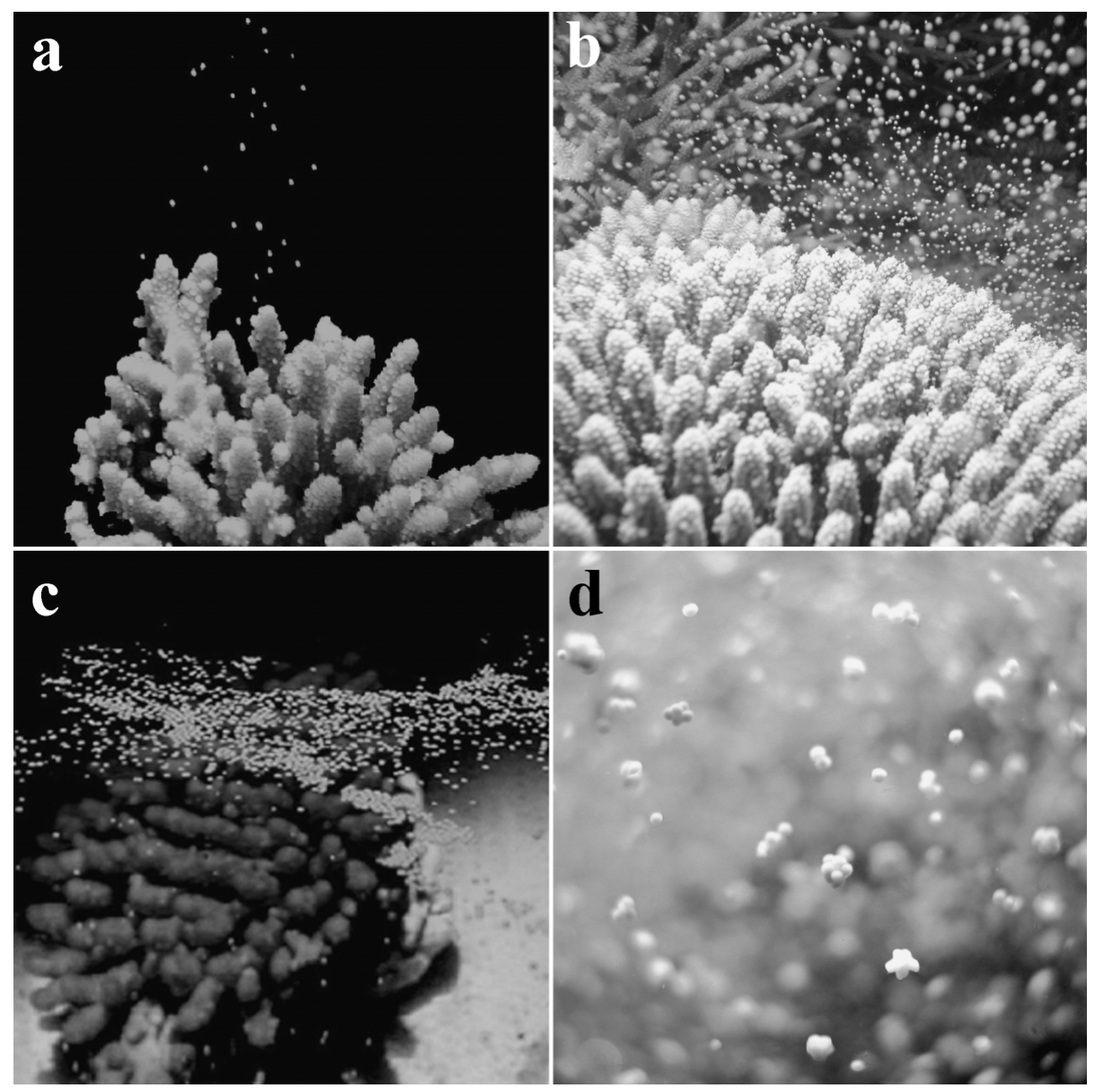

Fig. 2. Acropora spp. (a) Colony of Acropora millepora in aquarium releasing gametes during November spawning 2001; (b) hard corals of genus Acropora on Heron Island reef crest during main spawning event in November 2002; (c) egg-sperm bundle forms slick on water surface; (d) detail of egg-sperm bundles released by corals of genus Acropora

The corals in the aquarium showed a species-specific behaviour with Acropora millepora spawning on 9 November (8 fragments, 2 larger colonies) and 11 November (1 larger colony), and A. digitifera and A. pulchra spawning on 10 November (2 larger colonies each). A species-specific spawning behaviour was also observed by Hagman et al. (1998) for corals in the Gulf of Mexico.

Released egg-sperm bundles of 2 different colonies of Acropora pulchra (total vol. $=1 \mathrm{ml}$ ) incubated in aerated 11 glass beakers showed that the sperm and eggs separated within $30 \mathrm{~min}$. Sperm was then suspended in the water, whereas intact eggs floated at the water surface. The beakers were examined 5 times a day, the dead material was removed, and $10 \%$ of the water volume was replaced with fresh seawater. Within $48 \mathrm{~h}$, $50 \%$ of the eggs lost their coloration, died and sank to the beaker bottom. Pigmented eggs were still floating at the water surface after $48 \mathrm{~h}$, but subsequently gradually lost their positive buoyancy and changed to oval-shaped moving planula larvae. The latter were observed for the first time after $5 \mathrm{~d}$ incubation.

\section{Carbon and nitrogen in coral eggs}

Coral eggs released during the spawning event had a high carbon content of $57-66 \%$ (dry mass), whereas nitrogen accounted only for $3-4 \%$ of the egg dry mass (Table 1). Thus, the C:N ratio showed values of 16-21. There were no species-specific differences in $\mathrm{C}$ and $\mathrm{N}$ content.

\section{Egg release by Acropora spp.}

The measurements revealed a release of $19 \pm 15 \mathrm{~g}$ egg dry mass $\mathrm{m}^{-2}$ coral surface $(\mathrm{n}=8)$ by Acropora 
Table 1. Acropora spp. Carbon and nitrogen contents (mean \pm $\mathrm{SD}$ ) of eggs released by 3 species in relation to egg dry mass $(d m)$. n: no. of replicates

\begin{tabular}{|lcccc|}
\hline Species & $\mathrm{n}$ & $\begin{array}{c}\mathrm{C} \\
\left(\mathrm{mg} \mathrm{g}^{-1} \mathrm{dm}\right)\end{array}$ & $\begin{array}{c}\mathrm{N} \\
\left(\mathrm{mg} \mathrm{g}^{-1} \mathrm{dm}\right)\end{array}$ & $\begin{array}{c}\mathrm{C}: \mathrm{N} \\
\text { ratio }\end{array}$ \\
\hline A. digitifera & 6 & $572 \pm 59$ & $38 \pm 9$ & $16 \pm 4$ \\
A. pulchra & 3 & $659 \pm 43$ & $32 \pm 9$ & $21 \pm 4$ \\
A. millepora & 6 & $601 \pm 43$ & $36 \pm 4$ & $17 \pm 2$ \\
\hline
\end{tabular}

millepora during the November spawning event. This corresponds to at least 11.6 and $0.7 \mathrm{~g} \mathrm{C}$ and $\mathrm{N}$, respectively, released as eggs $\mathrm{m}^{-2}$ coral surface.

\section{In situ chamber experiments}

Despite the relatively small volume of gametes released during the spawning event, the benthic response to the organic matter input was immediate and strong. The average pre-spawning SOC of $94 \pm$ $2 \mathrm{mmol} \mathrm{m}^{-2} \mathrm{~d}^{-1}$ (mean $\pm \mathrm{SE}, \mathrm{n}=4$ ) increased by a factor of 2.5 to a maximum of $230 \mathrm{mmol} \mathrm{m}^{-2} \mathrm{~d}^{-1}$ on the second day after the spawning event (Fig. 3).

The decrease in the $\mathrm{O}_{2}$ consumption rate was nearly as steep as the increase; however, significantly ( $\alpha=0.025,1$-sided $U$-test: Wilcoxon, Mann-Whitney) higher SOC rates compared to pre-spawning values (5-8 November, $\mathrm{n}=5$ ) could still be measured $9 \mathrm{~d}$ after the spawning (Fig. 3).

SOC $11 \mathrm{~d}$ after the start of the spawning event was not significantly different from measured pre-spawning

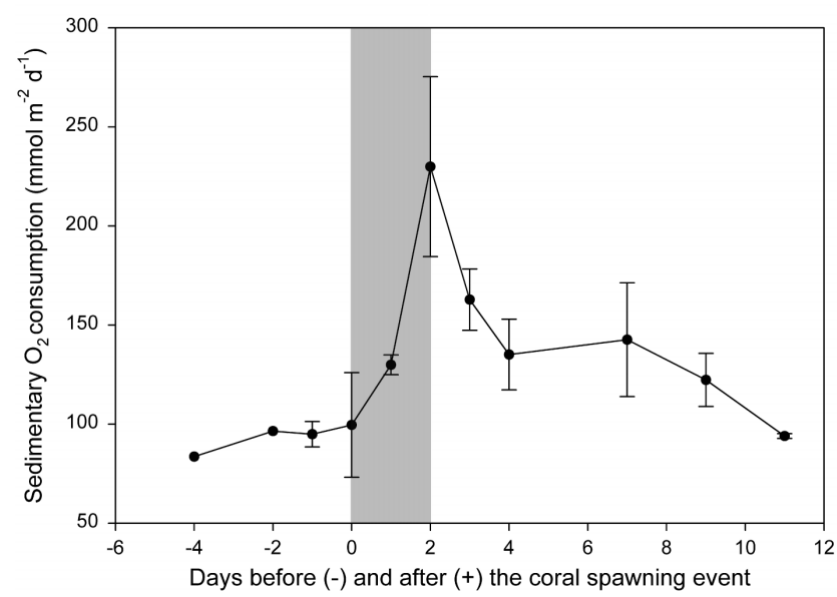

Fig. 3. Sedimentary $\mathrm{O}_{2}$ consumption (SOC) measured in 11 chamber experiments before, during and after coral Acropora spp. spawning period. Error bars $= \pm S D$. Number of replicate chambers $=1$ for first 2 experiments and 3 for remaining experiments. Point zero on abscissa indicates day on which spawning was first observed, grey area indicates all days on which spawning occurred values $(\alpha>0.2,2$-sided $U$-test: Wilcoxon, MannWhitney). SOC rates measured $11 \mathrm{~d}$ after the spawning event ranged from 93 to $95 \mathrm{mmol} \mathrm{m}^{-2} \mathrm{~d}^{-1}$. These values are at the upper limit of SOC values derived from in situ chamber incubations during the previous (52-80 mmol m $\mathrm{m}^{-2} \mathrm{~d}^{-1}, \mathrm{n}=3$ ) and following (49-92, $\mathrm{n}=6$ ) Australian summer at Heron Island outside the spawning period (Wild et al. 2004a,b).

\section{$\mathrm{O}_{2}$ consumption in the water column}

On 17 November, when SOC rates were still increasing, we measured an $\mathrm{O}_{2}$ consumption rate for Shark Bay waters of $15.4 \mu \mathrm{mol} \mathrm{l} \mathrm{l}^{-1} \mathrm{~d}^{-1}$, i.e. not higher than the values (between 5 and $41 \mu \mathrm{mol} \mathrm{l^{-1 }} \mathrm{d}^{-1}$ ) measured by C. Wild et al. (unpubl. data) in Shark Bay waters in January 2002. Using the water $\mathrm{O}_{2}$ consumption rate measured on 17 November to calculate the water $\mathrm{O}_{2}$ consumption in the benthic chambers (max. 71 ), this corresponds to a rate of $3.9 \mathrm{mmol} \mathrm{m} \mathrm{m}^{-2} \mathrm{~d}^{-1}$, i.e. about $3 \%$ of the $\mathrm{O}_{2}$ consumption rates of the previous (16 November: $142.6 \mathrm{mmol} \mathrm{m}^{-2} \mathrm{~d}^{-1}$ ) and following (18 November: $122.3 \mathrm{mmol} \mathrm{m}^{-2} \mathrm{~d}^{-1}$ ) days. This means that $>95 \%$ of the $\mathrm{O}_{2}$ consumption in the chambers was due to sedimentary metabolism and only a minor fraction to water column respiration.

\section{DISCUSSION}

In 2001, coral spawning at Heron Island was split into a minor November spawning event and a major December spawning event (S. Dove \& S. Ward pers. comm.). In 2002, this scenario was reversed, with a major spawning event in November and a smaller one in December (R. Tollrian pers. comm.). Fig. 2b shows a major spawning event on the Heron Island reef crest in November 2002.

In 2001, we were able to study the smaller event and showed that even a relatively small coral spawning can increase the SOC significantly for more than $1 \mathrm{wk}$. In order to explain the measured temporal link between the coral spawning event and the enhanced SOC rates, we must first assume that a fraction of the spawning products reached the sediment soon after release from the corals. This can occur through direct sedimentation of eggs, which is supported by our incubation experiments, where we observed that within $48 \mathrm{~h} 50 \%$ of the eggs lost their pigments, died and sank to the ground. Oliver \& Willis (1987) also observed that coral spawn slicks appearing on the days after coral spawning consisted to over $99 \%$ of dead eggs and breakdown products. Bacteria possibly degrade the low-density components (e.g. lipids) of this material, leading to loss 
of buoyancy and sedimentation of the dead spawning products.

A second source of organic matter may be the introduction of diluted sperm into the sediment. Sperm cells are not positively buoyant, and become diluted upon release from the egg-sperm bundles.

Additionally, spawning products can also reach the sediment via food-chain transfer processes. Many different coral reef organisms, e.g. fishes and zooplankton (Westneat \& Resing 1988, Baird et al. 2001, Pratchett et al. 2001) feed intensely on the spawning products and process them into faecal pellets. Faecal pellets are generally known to increase the sedimentary flux of organic material (Turner 2002).

All these factors lead to an increased sedimentation of organic matter derived from the spawning event. Regardless of how the spawning products reached the reef sediments, in these permeable reef sands advective processes play an important role in the rapid and efficient degradation of organic matter (Rasheed et al. 2004, Wild et al. 2004).

\section{Release of organic $\mathbf{C}$ and $\mathbf{N}$ during coral spawning event}

Corals of the genus Acropora cover $15.7 \%$ of the Heron Island rim, which includes the reef crest and slope (A. Klueter unpubl. data). From a satellite picture we calculated that the Heron Island rim covers a total area of about $6.9 \mathrm{~km}^{2}$. Hard corals of the genus Acropora therefore exclusively cover approximately $1.1 \mathrm{~km}^{2}$ of the Heron Island reef rim. Because of the 3-dimensional structure of the corals, this Acroporacovered rim-surface area corresponds to an actual coral-surface area 3.8-fold larger (approx. $4.2 \mathrm{~km}^{2}$ ). Our results show that $11.6 \mathrm{~g} \mathrm{C}$ and $0.7 \mathrm{~g} \mathrm{~N}$ were released $\mathrm{m}^{-2}$ coral surface by the staghorn coral $A$. millepora as eggs during the coral spawning event in 2001. Extrapolated to the reef-rim area and assuming that the other Acropora species release roughly the same amount of eggs, this would account for a release of $7.1 \mathrm{~g} \mathrm{C}$ and $0.4 \mathrm{~g} \mathrm{~N} \mathrm{~m}^{-2}$. Our data further suggest that all hard corals from Heron Island may release roughly $310 \mathrm{t} \mathrm{C}$ and $18 \mathrm{t} \mathrm{N}$ as eggs during spawning; the simultaneous release of sperm is not included in this estimate.

\section{Effect of coral spawning on SOC}

With values exceeding $200 \mathrm{mmol} \mathrm{m}^{-2} \mathrm{~d}^{-1}$, the SOC in the coarse carbonate sands of Heron Island after the spawning event reached rates exceeding those measured in most coastal sediments (Table 2). Higher SOC rates are measured only in microbially highly active sediments, e.g. those beneath cages of a salmon farm (Nickell et al. 2003). Diffusive oxygen uptake rates of the seafloor range usually between 10 and $30 \mathrm{mmol}$ $\mathrm{m}^{-2} \mathrm{~d}^{-1}$, with maximum rates of approximately 94

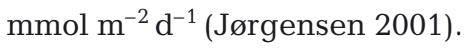

Ehrenhauß \& Huettel (2004) simulated the sedimentation of a phytoplankton bloom by adding dead diatoms (amount of added material comparable to the amount of material reaching the sediment after a spring algal bloom) to benthic chambers identical to those used in this study. The SOC in very fine to coarse sands from the German North Sea increased afterwards by a factor of 2.0-3.3, similar to the maximum increase observed in this study. This indicates that the coral spawning event may have a similar effect on SOC as sedimentation during an algal bloom. The measured SOC rates in the silicate sediments (63-1000 $\mu \mathrm{m}$ grain size) used by Ehrenhauß \& Huettel (2004) were between 1.2 and $6.7 \mathrm{mmol} \mathrm{m}^{-2} \mathrm{~d}$ (without algae addition) and $6.7-11.0 \mathrm{mmol} \mathrm{m}^{-2} \mathrm{~d}^{-1}$ (after algae addition), indicating that much more organic matter can be mineralised in the carbonate sands from Heron Island with a similar grain size $(838 \mu \mathrm{m})$.

SOC was enhanced compared to the pre-spawning level $\left(94 \pm 2 \mathrm{mmol} \mathrm{m}^{-2} \mathrm{~d}^{-1}\right)$ for $9 \mathrm{~d}$ after the spawning

Table 2. Sedimentary $\mathrm{O}_{2}$ consumption (SOC) measured in different marine shelf sediments with benthic chamber incubations

\begin{tabular}{|llll}
\hline Location & SOC & Sediment & Source \\
\hline Douro River Estuary (Portugal) & $<96$ & Silicates & Magalhaes et al. (2002) \\
Salmon farm, Loch Creran (Scotland) & $9-468$ & Silicates & Nickell et al. (2003) \\
North and Baltic Sea & $42-170$ & Silicates & Forster et al. (1999) \\
Balearic Islands (Spain) & 195 & Silicates & Lopez et al. (1995) \\
Bay of Cadiz (Spain) & 138 & Silicates & Forja et al. (1994) \\
Shellfish farm, Carteau Bay (France) & $<105$ & Silicates & Barranguet et al. (1994) \\
Bay of Cadiz (Spain) & $99-189$ & Silicates & Marinelli et al. (1998) \\
South Atlantic Bight & 35 & Silicates & Grenz et al. (2003) \\
New Caledonia & $11-54$ & Carbonates & Boucher et al. (1994) \\
New Caledonia & 18 & Carbonates & This study \\
Heron Island & $84-230$ & Carbonates & \\
\hline
\end{tabular}


event (see Fig. 3). Integration of the additional SOC due to the spawning event (measurements were interpolated for days on which no measurements were made) results in $490 \mathrm{mmol} \mathrm{O}_{2} \mathrm{~m}^{-2}$. If it is assumed that $1 \mathrm{~mol}$ of $\mathrm{O}_{2}$ oxidises $1 \mathrm{~mol}$ of reduced carbon (in this case coral eggs), then $41 \mathrm{mg}$ of $\mathrm{C}$ was oxidised $\mathrm{m}^{-2}$ Heron Island reef flat area during the $9 \mathrm{~d}$ period. This is equivalent to $800 \mathrm{~kg} \mathrm{C}$ for the entire reef flat area of $19.5 \mathrm{~km}^{2}$. We calculated a possible egg production of 66 t C for Acropora spp. and 310 t C for all hard corals of the Heron Reef (see preceding subsection). As such, between $0.2 \%$ (spawning of all hard corals) and 1.6\% (only Acropora spp. spawned) of the egg dry mass could have produced the observed increase in the SOC rate.

These numbers may be even smaller, since we could not include the organic matter derived from coral sperm in this calculation. The sedimentary community can rapidly degrade sperm, which is diluted and transported into the permeable sediments via advection. However, it cannot be concluded that only a very small fraction of all coral eggs is degraded in the reef system. The shallow location where the chamber measurements were carried out is exposed to tidal currents and waves. Thus, sedimentation of low-density material such as spawning products in this area is impeded and therefore relatively small. Much higher sedimentation of spawning products can be expected in deeper or calm parts of the lagoon, as supported by reports of Wolanski et al. (1989) and Simpson et al. (1993).

The fast SOC response of the Heron Island sediments hints at a rapid input of organic matter to the sediments. The effect of the spawning event, however, is not restricted to additional $\mathrm{C}$ and $\mathrm{N}$ being released to the reef. Atkinson \& Atkinson (1992) reported that during a coral spawning event the total phosphate concentrations in the water column increased 600-fold. High P concentrations in the water column can stimulate the growth of bacteria in the water column and in the sediment of oligotrophic reef systems (Kuffner \& Paul 2001). This may also have contributed to the high SOC rates observed in this study.

Even a small coral spawning event, such as that we studied, supplies enough organic material and nutrients to maintain sedimentary metabolism above the initial level for at least $1 \mathrm{wk}$. A more pronounced spawning (such as the November spawning event in 2002: Fig. 2b) or split-spawning could cause an increased SOC level over an even longer period of time.

Our findings show that coral spawning events may play a periodical but important role in the nutrition of benthic (microbial) reef communities. The result of this study hint at an important trophic link between the corals and the sedimentary community, especially during the spawning period, in addition to the proposed trophic link via spawning products between corals and reef fishes (Pratchett et al. 2001).

The trapping of spawning products in the reef lagoon and the rapid processing of the products by reef organisms reduces the loss of organic matter from the reef, and therefore represents a recycling process that retains and accumulates nutrients in the oligotrophic reef system.

Acknowledgements. We thank Bo Barker Jørgensen for his support of this work. Thanks are also due to L. Hönemann who helped with the $\mathrm{C} / \mathrm{N}$ analyses. We acknowledge $\mathrm{R}$. Forbes of Heron Island Research Station (HIRS) for logistical assistance and $\mathrm{S}$. Ward for taxonomic advice. Thanks are due to P. Cook, who helped improve the manuscript. All sample collections and in situ experiments were done under Permit G01/479 of the Great Barrier Reef Marine Park Authority. This research was funded by the Max Planck Society (MPG), Germany.

\section{LITERATURE CITED}

Andrews J, Gay S, Sammarco P (1989) Influence of circulation on self-seeding patterns at Helix Reef, Great Barrier Reef. Proc 6th Int Coral Reef Symp 2:469-474

Arai T, Kato M, Heyward A, Ikeda Y, Iizuka T, Maruyama T (1993) Lipid-composition of positively buoyant eggs of reef building corals. Coral Reefs 12:71-75

Atkinson S, Atkinson MJ (1992) Detection of estradiol-17-beta during a mass coral spawn. Coral Reefs 11:33-35

Babcock RC, Bull GD, Harrison PL, Heyward AJ, Oliver JK, Wallace CC, Willis BL (1986) Synchronous spawning of 105 scleractinian coral species on the Great Barrier Reef. Mar Biol 90:379-394

Baird AH, Pratchett MS, Gibson DJ, Koziumi N, Marquis CP (2001) Variable palatability of coral eggs to a planktivorous fish. Mar Freshw Res 52:865-868

Barranguet C, Alliot E, Plantecuny MR (1994) Benthic microphytic activity at 2 Mediterranean shellfish cultivation sites with reference to benthic fluxes. Oceanol Acta 17:211-221

Boucher G, Clavier J, Garrigue C (1994) Oxygen and carbondioxide fluxes at the water-sediment interface of a tropical lagoon. Mar Ecol Prog Ser 107:185-193

Clifton KE (1997) Mass spawning by green algae on coral reefs. Science 275:1116-1118

Coll JC, Bowden BF, Meehan GV, Konig GM and 14 others (1994) Chemical aspects of mass spawning in corals. 1. Sperm-attractant molecules in the eggs of the scleractinian coral Montipora digitata. Mar Biol 118:177-182

Ehrenhauß S, Huettel M (2004) Advective transport and decomposition of chain-forming planktonic diatoms in permeable sediments. J Sea Res (in press)

Forja JM, Blasco J, Gomezparra A (1994) Spatial and seasonal variation of in situ benthic fluxes in the Bay of Cadiz (south-west Spain). Estuar Coast Shelf Sci 39:127-141

Forster S, Glud RN, Gundersen JK, Huettel M (1999) In situ study of bromide tracer and oxygen flux in coastal sediments. Estuar Coast Shelf Sci 49:813-827

Gittings SR, Boland GS, Deslarzes KJP, Combs CL, Holland BS, Bright TJ (1992) Mass spawning and reproductive viability of reef corals at the East Flower Garden Bank, Northwest Gulf of Mexico. Bull Mar Sci 51:420-428

Glud RN, Gundersen JK, Revsbech NP, Jørgensen BB, Huettel 
M (1995) Calibration and performance of the stirred flux chamber from the benthic lander Elinor. Deep-Sea Res Part II Oceanogr Res 42:1029-1042

Gomezparra A, Forja JM (1993) Benthic nutrient fluxes in Cadiz Bay (SW Spain). Hydrobiologia 252:23-34

Grenz C, Denis L, Boucher G, Chauvaud L, Clavier J, Fichez R, Pringault O (2003) Spatial variability in sediment oxygen consumption under winter conditions in a lagoonal system in New Caledonia (South Pacific). J Exp Mar Biol Ecol 285:33-47

Guest JR, Chou LM, Baird AH, Goh BPL (2002) Multispecific, synchronous coral spawning in Singapore. Coral Reefs 21:422-423

Hagman D, Gittings S, Deslarzes K (1998) Timing, species participation, and environmental factors influencing annual mass spawning at the Flower Garden Banks (Northwest Gulf of Mexico). Gulf Mex Sci 16:170-179

Harriott VJ (1992) Recruitment patterns of scleractinian corals in an isolated subtropical reef system. Coral Reefs 11: 215-219

Harrison PL (1993) Coral spawning on the Great Barrier Reef. Search 24:45-48

Harrison PL, Babcock RC, Bull GD, Oliver JK, Wallace CC, Willis BL (1984) Mass spawning in tropical reef corals. Science 223:1186-1189

Hayashibara T, Shimoike K, Kimura T, Hosaka S, Heyward A, Harrison P, Kudo K, Omori M (1993) Patterns of coral spawning at Akajima Island, Okinawa, Japan. Mar Ecol Prog Ser 101:253-262

Huettel M, Gust G (1992) Solute release mechanisms from confined sediment cores in stirred benthic chambers and flume flows. Mar Ecol Prog Ser 82:187-197

Hughes TP, Baird AH, Dinsdale EA, Moltschaniwskyj NA, Pratchett MS, Tanner JE, Willis BL (2000) Supply-side ecology works both ways: the link between benthic adults, fecundity, and larval recruits. Ecology 81:2241-2249

Jørgensen BB (2001) Life in the diffusive boundary layer. In: Boudreau BP, Jørgensen BB (eds) The benthic boundary layer. Oxford University Press, Oxord, New York, p 395

Klute A, Dirksen C (1986) Hydraulic conductivity and diffusivity: laboratory methods. In: Klute A (ed) Methods of soil analysis, Part 1. Physical and mineralogical methods, 2nd edn. American Society of Agronomy, Madison, WI

Kuffner IB, Paul VJ (2001) Effects of nitrate, phosphate and iron on the growth of macroalgae and benthic cyanobacteria from Cocos Lagoon, Guam. Mar Ecol Prog Ser 222: $63-72$

Lasker H, Brazeau D, Claderon J, Coffroth M, Coma R, Kim K (1996) In situ rates of fertilization among broadcast spawning gorgonian corals. Biol Bull (Woods Hole) 190:45-55

Lopez P, Vidal M, Lluch X, Morgui JA (1995) Sediment metabolism in a transitional continental marine area-the Albufera-Fo-Majorca (Balearic Islands, Spain). Mar Freshw Res 46:45-53

Magalhaes CM, Bordalo AA, Wiebe WJ (2002) Temporal and spatial patterns of intertidal sediment-water nutrient and oxygen fluxes in the Douro River estuary, Portugal. Mar Ecol Prog Ser 233:55-71

Marinelli RL, Jahnke RA, Craven DB, Nelson JR, Eckman JE (1998) Sediment nutrient dynamics on the South Atlantic Bight continental shelf. Limnol Oceanogr 43:1305-1320

Editorial responsibility: Otto Kinne (Editor), Oldendorf/Luhe, Germany
Nickell LA, Black KD, Hughes DJ, Overnell J, Brand T, Nickell TD, Breuer E, Harvey SM (2003) Bioturbation, sediment fluxes and benthic community structure around a salmon cage farm in Loch Creran, Scotland. J Exp Mar Biol Ecol 285:221-233

Oliver JK, Willis BL (1987) Coral-spawn slicks in the Great Barrier Reef-preliminary observations. Mar Biol 94: 521-529

Oliver JK, Babcock R, Harrison P, Willis BL (1988a) Geographic extent of mass coral spawning: clues to ultimate causal factors. Proc 6th Int Coral Reef Symp 2:803-810

Pratchett MS, Gust N, Goby G, Klanten SO (2001) Consumption of coral propagules represents a significant trophic link between corals and reef fish. Coral Reefs 20:13-17

Rasheed M, Wild C, Franke U, Huettel M (2004) Benthic photosynthesis and oxygen consumption in permeable carbonate sediments at Heron Island, Great Barrier Reef, Australia. Estuar Coast Shelf Sci 59:139-150

Sammarco P, Andrews J, Risk M (1991) Coral reef geomorphology as a function of seasonal prevailing currents and larval dispersal. Palaeogr Palaeoclimatol Palaeoecol 88: $1-12$

Shlesinger Y, Loya Y (1985) Coral community reproductive patterns: Red Sea versus the Great Barrier Reef. Science 228:1333-1335

Simpson CJ, Cary JL, Masini RJ (1993) Destruction of corals and other reef animals by coral spawn slicks on Ningaloo Reef, Western Australia. Coral Reefs 12:185-191

Soong K, Cho LC (1998) Synchronized release of medusae from three species of hydrozoan fire corals. Coral Reefs $17: 145-154$

Stimson J, Kinzie RA (1991) The temporal pattern and rate of release of zooxanthellae from the reef coral Pocillopora damicornis (Linnaeus) under nitrogen enrichment and control conditions. J Exp Mar Biol Ecol 153:63-74

Szmant AM (1986) Reproductive ecology of Caribbean reef corals. Coral Reefs 5:43-53

Turner JT (2002) Zooplankton fecal pellets, marine snow and sinking phytoplankton blooms. Aquat Microb Ecol 27: 57-102

Van Woesik R (1995) Coral communities at high latitude are not pseudopopulations: evidence of spawning at 32 degree N, Japan. Coral Reefs 14:119-120

Westneat M, Resing J (1988) Predation on coral spawn by planktivorous fish. Coral Reefs 7:89-92

Wild C, Rasheed M, Werner U, Franke U, Johnstone R, Huettel M (2004a) Degradation and mineralization of coral mucus in reef environments. Mar Ecol Prog Ser 267:159-171

Wild C, Huettel M, Klueter A, Kremb SG, Rasheed M, Jørgensen BB (2004b) Coral mucus functions as an energy carrier and particle trap in the reef ecosystem. Nature 428:66-70

Willis BL, Oliver JK (1990) Direct tracking of coral larvaeimplications for dispersal studies of planktonic larvae in topographically complex environments. Ophelia 32:145-162

Winkler LW (1888) The determination of dissolved oxygen in water. Ber Dtsch Chem Ges 21:2843-2857

Wolanski E, Burrage D, King B (1989) Trapping and dispersion of coral eggs around Bowden Reef, Great Barrier Reef, following mass coral spawning. Contin Shelf Res 9: 479-496

Submitted: July 31, 2003; Accepted: January 15, 2004 Proofs received from author(s): April 8, 2004 